University of Nebraska - Lincoln

DigitalCommons@University of Nebraska - Lincoln

2-24-2005

\title{
Medieval Warming, Little Ice Age, and European impact on the environment during the last millennium in the lower Hudson Valley, New York, USA
}

\author{
Dee Cabaniss Pederson \\ Lamont-Doherty Earth Observatory, dcp@Ideo.columbia.edu \\ Dorothy M. Peteet \\ NASA/Goddard Institute for Space Studies \\ Dorothy Kurdyla \\ Center for Accelerated Mass Spectrometry \\ Tom Guilderson \\ Center for Accelerated Mass Spectrometry
}

Follow this and additional works at: https://digitalcommons.unl.edu/nasapub

Part of the Physical Sciences and Mathematics Commons

Pederson, Dee Cabaniss; Peteet, Dorothy M.; Kurdyla, Dorothy; and Guilderson, Tom, "Medieval Warming, Little Ice Age, and European impact on the environment during the last millennium in the lower Hudson Valley, New York, USA" (2005). NASA Publications. 19.

https://digitalcommons.unl.edu/nasapub/19

This Article is brought to you for free and open access by the National Aeronautics and Space Administration at DigitalCommons@University of Nebraska - Lincoln. It has been accepted for inclusion in NASA Publications by an authorized administrator of DigitalCommons@University of Nebraska - Lincoln. 


\title{
Medieval Warming, Little Ice Age, and European impact on the environment during the last millennium in the lower Hudson Valley, New York, USA
}

\author{
Dee Cabaniss Pederson ${ }^{\mathrm{a}, *}$, Dorothy M. Peteet ${ }^{\mathrm{a}, \mathrm{b}}$, Dorothy Kurdyla ${ }^{\mathrm{c}}$, Tom Guilderson ${ }^{\mathrm{c}}$ \\ ${ }^{a}$ Lamont-Doherty Earth Observatory, 61 Rte. 9W, Palisades, NY 10964, USA \\ ${ }^{\mathrm{b}}$ NASA/Goddard Institute for Space Studies, 2880 Broadway, New York, NY 10025, USA \\ ${ }^{\mathrm{c}}$ Lawrence Livermore National Laboratory, Center for Accelerated Mass Spectrometry, 7000 East Avenue, L-403, Livermore, CA 94550, USA
}

Received 9 March 2004

Available online 24 February 2005

\begin{abstract}
Establishing natural climate variability becomes particularly important in large urban areas in anticipation of droughts. We present a welldated bi-decadal record of vegetation, climate, land use, and fire frequency from a tidal marsh in the Hudson River Estuary. The classic Medieval Warm Period is evident through striking increases in charcoal and Pinus dominance from 800-1300 A.D., paralleling paleorecords southward along the Atlantic seaboard. Higher inputs of inorganic sediment during this interval suggest increased watershed erosion during drought conditions. The presence of the Little Ice Age ensues with increases in Picea and Tsuga, coupled with increasing organic percentages due to cooler, moister conditions. European impact is manifested by a decline in arboreal pollen due to land clearance, increased weedy plant cover (i.e., Ambrosia, Plantago, and Rumex), and an increase in inorganic particles to the watershed.
\end{abstract}

(C) 2005 University of Washington. All rights reserved.

Keywords: Pollen; Charcoal; Climate; Medieval Warming; Little Ice Age; Land use; Hudson Valley; Phragmites; Typha

\section{Introduction}

Prediction of long-term drought has become a major topic at the forefront of climate change research (i.e., Trenberth et al., 2004). Droughts in the Hudson River Valley have been documented for recent centuries (Cook and Jacoby, 1977). However, millennial-scale records for the region are lacking, making it difficult to place the anthropogenic era in historical context. Longer records are crucial for estimating natural variations in climate that affect the Hudson River watershed, which provides water resources for New York City's 8 million inhabitants. Defining a detailed Hudson record of climate change to compare with regional (Cronin et al., 2003; Stahle et al.,

\footnotetext{
* Corresponding author. Fax: +1 8453658154 .

E-mail address: dcp@ldeo.columbia.edu (D.C. Pederson).
}

1988; Willard and Korejwo, 1999; Willard et al., 2003) and North Atlantic records (Bond et al., 2001; Keigwin, 1996) will improve our understanding of the forcing for these changes along the Atlantic seaboard. The unusually high sedimentation rate (avg. $0.2 \mathrm{~cm} / \mathrm{yr}$ ) in Piermont Marsh, New York is unique among Hudson marshes (Merley and Peteet, 2001; Newman et al., 1987; Peteet and Wong, 1999) and affords an opportunity to investigate the detailed continuous environmental history of the Hudson River watershed at bi-decadal to centennial resolution. Here, we present pollen and spores, charcoal, loss-on-ignition (LOI), and marsh sediment composition data for the last 1350 calendar yr.

Using the Piermont record, we address the following questions: (1) What was the pre-European forest and marsh composition? (2) Is a climate signal present in the shifts in pre-European vegetation and charcoal? (3) How does preEuropean variability compare with anthropogenically induced change? (4) How do organic and inorganic 
sediment composition compare with vegetation shifts and the charcoal record?

\section{Study location}

Piermont Marsh $\left(41^{\circ} 00^{\prime} \mathrm{N}, 73^{\circ} 55^{\prime} \mathrm{W}\right)$, located on the western shore of the Hudson River and approximately 40 $\mathrm{km}$ north of the river's mouth (Fig. 1), is one of four National Estuarine Research Reserve (NERR) sites along the river. It measures 110 ha and is bounded by Piermont Pier to the north and the Palisades sill to the west, which rises $\sim 100 \mathrm{~m}$ to form Tallman State Park. Mean salinity is $6.0 \mathrm{ppt}$, and the marsh is categorized as brackish (Winogrond, 1997). Two creeks, the freshwater Sparkill and the brackish Crumkill, meander through the marsh (Fig. 1b). Marsh vegetation is comprised primarily of Phragmites australis, but Spartina alterniflora, Spartina patens, Spartina cynosuroides, Schoenoplectus robustus, Schoenoplectus americanus, Typha angustifolia, Iva frutescens, Chenopodium glaucum (introduced), and Chenopodium ambrosioidies (introduced) are present (Blair and
Nieder, 1993; Lehr, 1967). Due to the sharp rise of the Palisades Sill to the west, Sparkill Creek to the north, and the river contour to the south, the marsh is circumscribed with negligible marsh fringe. Because it is so limited aerially and cannot "expand" landward, the marsh area and its local wetland contribution are relatively constant over time. It is the northernmost site of Spartina in the Hudson Estuary, and no native Chenopodiaceae are found in the marsh flora today. However, dramatic changes in marsh vegetation have taken place over the last $50 \mathrm{yr}$ with the advent of invasive species. $P$. australis colonies have increased their percent coverage of the marsh from 35 to $40 \%$ in 1965 to $66 \%$ in 1991 (Winogrond, 1997). A detailed doctoral thesis study of Piermont Marsh hydrology demonstrates that our coring site location in high marsh $S$. patens/Distichlis is saturated throughout the tidal cycle, in contrast to the creek margin $S$. alterniflora vegetation that is not saturated during ebb tide (F. Montalto, personal communication, 2003). The lack of channel deposits in the section indicates no major changes in the courses of the marsh tributaries at our site.

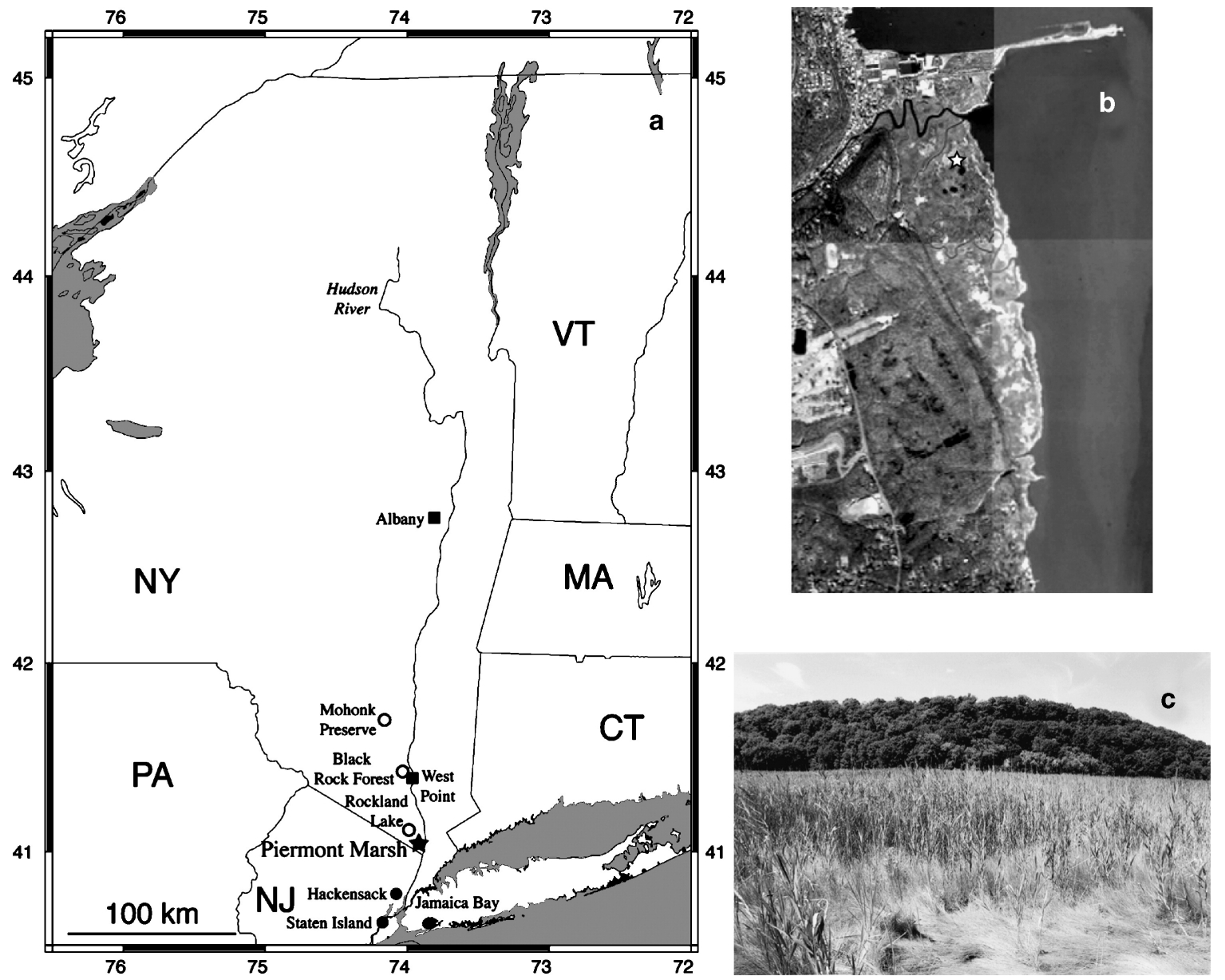

Figure 1. (a) Hudson Valley region with Piermont Marsh marked with a star. Filled circles designate regional marsh records, and unfilled circles mark upland records. (b) Aerial view of Piermont Marsh bounded to the north by the pier built in 1854. A star marks the core location. Sparkill Creek is the large tributary through the northern portion of the marsh. Tallman State Park forms the western boundary to an elevation of $\sim 100$ m. (c) Photograph of Tallman State Park from the core site. In the foreground, the remnant Spartina patens/Distichlis is present with Typha and Phragmites in the background. Tallman mountain rises to the west. 
Local forest composition in promontory Tallman State Park reflects regional diversity, consisting of a QuercusCarya (oak-hickory) assemblage on the more shallow soils. Northern hardwoods (Acer saccharum (sugar maple), Fagus americana (American beech), and Betula spp. (birch)) and southern temperate trees (Liriodendron tulipifera (tulip poplar), Liquidambar styraciflua (sweet gum)) are found on more mesic sites. Pinus strobus (white pine) and Tsuga spp. (hemlock) are also present.

Southeastern New York experiences a mixture of continental and maritime climates. Mean annual precipitation is $1080 \mathrm{~mm}$. Mean temperatures for January and July in New York City are $-0.4^{\circ} \mathrm{C}$ and $25^{\circ} \mathrm{C}$, respectively (www.ncdc.noaa.gov, Central Park Observatory).

\section{Materials and methods}

The core site represents the remnant $S$. patens/Distichlis vegetation in the northcentral portion of the marsh (Fig. 1c). The upper $2 \mathrm{~m}$ was taken with a Hiller peat corer in June 2000 about $25 \mathrm{~cm}$ away from deeper sediment extractions (i.e., 2-3 $\mathrm{m}$ ) using the modified Livingston piston corer (Wright et al., 1984). Due to difficulties with the Livingston corer in obtaining good recovery in the upper sediments, we used the Hiller corer for the upper $2 \mathrm{~m}$. Recovery of the study intervals was $100 \%$ (both Livingston and Hiller cores). Field subsamples were refrigerated prior to analysis. Samples for pollen analysis and LOI were taken at $4-\mathrm{cm}$ intervals throughout the $246 \mathrm{~cm}$ used in this study. Nomenclature follows FNAEC (1993). LOI was measured according to Dean (1974).

All samples for pollen analysis were prepared according to standard procedures (Faegri and Iversen, 1975; Heusser and Stock, 1984). Pollen residues were dehydrated in alcohols and suspended in silicone oil. Pollen and spores were identified according to the reference collection at LDEO and reference books (Kapp et al., 2000; Lewis et al., 1983; Moore and Webb, 1978). For each sample, a minimum of 300 non-aquatic pollen grains were counted at $400 \times$ magnification. Because Typha (cattail), which was tallied as an aquatic type, accounts for a large percentage of the total pollen in portions of the record, a minimum of 300 non-aquatic grains were counted for each sample to gain a more accurate vegetation signature. Pollen percentages are based on sums of arboreal and herbaceous pollen. Typha percentages are based on sums of arboreal, herbaceous, and aquatic pollen grains. Because the pollen sum includes upland as well as wetland taxa, interpretation of wetland development is not the object of this study. Here, we describe changes in the watershed through time. Comparison with regional lake records is possible, however, since the upland component of the core is statistically significant ( $\sim 300$ grains). Spore percentages are based on the sum of pollen and spores. Pollen diagrams were produced using Tilia and Tiliagraph (Grimm, 1992).

Separation of pollen to species was achieved for $T$. angustifolia, T. latifolia, T. glauca, and Sparganium based on the morphological work of Finkelstein (2003). T. angustifolia was counted as a monad, T. latifolia as a tetrad, and T. glauca as a dyad. Sparganium was differentiated from Typha based on differences in angularity described by Finkelstein (2003). Phragmites was separated from other Poaceae pollen grains on the basis of its small size (Clark and Patterson, 1985). The separations are featured in Figure 7.

Seventeen macrofossil samples from the top $278 \mathrm{~cm}$ of the core were sent to Lawrence Livermore National Labs (LLNL)

Table 1

Age ranges for $95.4 \%$ enclosed area are shown for the calendar used range in calendar calculation

\begin{tabular}{|c|c|c|c|c|}
\hline Sample depth $(\mathrm{cm})$ & Items analyzed & $\begin{array}{l}\text { Uncorrected }{ }^{14} \mathrm{C} \\
\text { year B.P. age }\end{array}$ & $\begin{array}{l}\text { Calibrated 2-sigma age } \\
\text { range (cal year A.D.) }\end{array}$ & $\begin{array}{l}\text { Calendar age } \\
\text { (cal yr A.D.) }\end{array}$ \\
\hline $80-84$ & 4 black Schoenoplectus seeds & $145 \pm 40^{*}$ & $1667-1783(46 \%)$ & $1725^{*}$ \\
\hline $88-92$ & woody long stem & modern & & \\
\hline $96-100$ & 6 black medium Schoenoplectus seeds & $270 \pm 40^{*}$ & $1609-1673(42 \%)$ & $1641^{*}$ \\
\hline $92-96$ & 7 black Schoenoplectus seeds & $275 \pm 40^{*}$ & $1608-1671(40 \%)$ & $1640^{*}$ \\
\hline $108-112$ & Schoenoplectus stem & $355 \pm 35$ & $1539-1636(57 \%)$ & 1588 \\
\hline $120-124$ & 2 Schoenoplectus nodes & $520 \pm 35^{*}$ & $1391-1444(86 \%)$ & $1418^{*}$ \\
\hline $132-136 a$ & 1 sedge node, 1 Eleocharis seed & $515 \pm 45$ & $1386-1454(79 \%)$ & 1420 \\
\hline $132-136 b$ & 1 Dirca-type seed, 5 yellow Schoenoplectus seeds & $600 \pm 60^{*}$ & $1291-1425(100 \%)$ & $1358 *$ \\
\hline $140-144$ & 2 sedge nodes, 1 woody fragment & $455 \pm 35$ & $1408-1487(100 \%)$ & 1448 \\
\hline $148-152$ & $\begin{array}{l}1 \text { black Schoenoplectus, } 2 \text { yellow Schoenoplectus } \\
\text { seeds }\end{array}$ & $660 \pm 70^{*}$ & $1245-1417(100 \%)$ & $1331 *$ \\
\hline $168-172$ & 3 charcoal pieces, 1 large Schoenoplectus seed & $70 \pm 40$ & $1876-1917(44 \%)$ & \\
\hline $176-180$ & $\begin{array}{l}2 \text { black medium Schoenoplectus seeds, } \\
3 \text { Eleocharis seeds, } 1 \text { white Carex seed }\end{array}$ & $785 \pm 45^{*}$ & $1179-1294(100 \%)$ & $1237^{*}$ \\
\hline $184-188$ & 1 Cladium, 1 Carex, 2 yellow Schoenoplectus seeds & $1035 \pm 45^{*}$ & $894-1043(92 \%)$ & $969 *$ \\
\hline $188-192$ & 2 sedge nodes, 2 woody fragments & $1300 \pm 35$ & $660-777(100 \%)$ & 719 \\
\hline $192-196$ & 2 charcoal stems & $1030 \pm 40$ & $940-1043(84 \%)$ & 992 \\
\hline $214-216$ & 1 Cladium, 5 yellow Schoenoplectus seeds & $1210 \pm 40^{*}$ & $758-897(81 \%)$ & $828 *$ \\
\hline $276-278$ & 2 Polygonum seeds & $1580 \pm 80^{*}$ & $336-640(98 \%)$ & $488^{*}$ \\
\hline
\end{tabular}

Relative percent area represented by the calendar range is shown in parentheses ( ). Selected dates are marked by an asterisk (*). 
for AMS-radiocarbon dating. The depths and types of macrofossils for all dated samples are presented in Table 1. Sediment accumulation rates were calculated using linear interpolation between the ${ }^{14} \mathrm{C}$ dates (Fig. 2). The core top was estimated at 0 cal yr B.P. (the core was obtained in A.D. 2000, calendar dates obtained with CALIB 4.4 were adjusted from A.D. 1950) because there was no indication of disturbance.

Use of microscopic charcoal as a fire indicator has been the topic of numerous studies (e.g., Clark, 1988; Tinner and $\mathrm{Hu}, 2003)$. Clark (1988) examines the controversies of using pollen-slide charcoal counts and, using particle motion theory concludes that the small charcoal particles counted in most studies $(5-10 \mu \mathrm{m})$ yield ambiguous charcoal records. In this study, charcoal pieces $>50 \mu \mathrm{m} \times 10 \mu \mathrm{m}\left(500 \mu \mathrm{m}^{2}\right)$ were counted along with pollen grains and exotic Lycopodium. The size criterion was chosen to avoid confusion of microscopic charcoal with opaque mineral material, which is typically $<50 \mu \mathrm{m}$ in one dimension (Clark and Patterson, 1984; Parshall and Foster, 2002). The criterion is also in agreement with Clark's (1988) assertion that thin-section charcoal (minimum size $=50 \mu \mathrm{m}$ ) better represents local fire events (Clark and Robinson, 1993). We note that those intervals with more charcoal $>50 \mu \mathrm{m}$ also had more small charcoal fragments $(<50 \mu \mathrm{m})$. Although charcoal is primarily transported by wind and water, the size used in this study reflects particles from local origin $(<20 \mathrm{~km}$ if convection column reaches $1000 \mathrm{~m}$; Clark, 1988). Identified macrofossil charcoal in the samples at various intervals (D. Peteet, unpublished data, 2002) supports local fires in the marsh itself. However, because the marsh floods twice a day, it is possible that some of the wood charcoal reflects fires in the larger watershed.

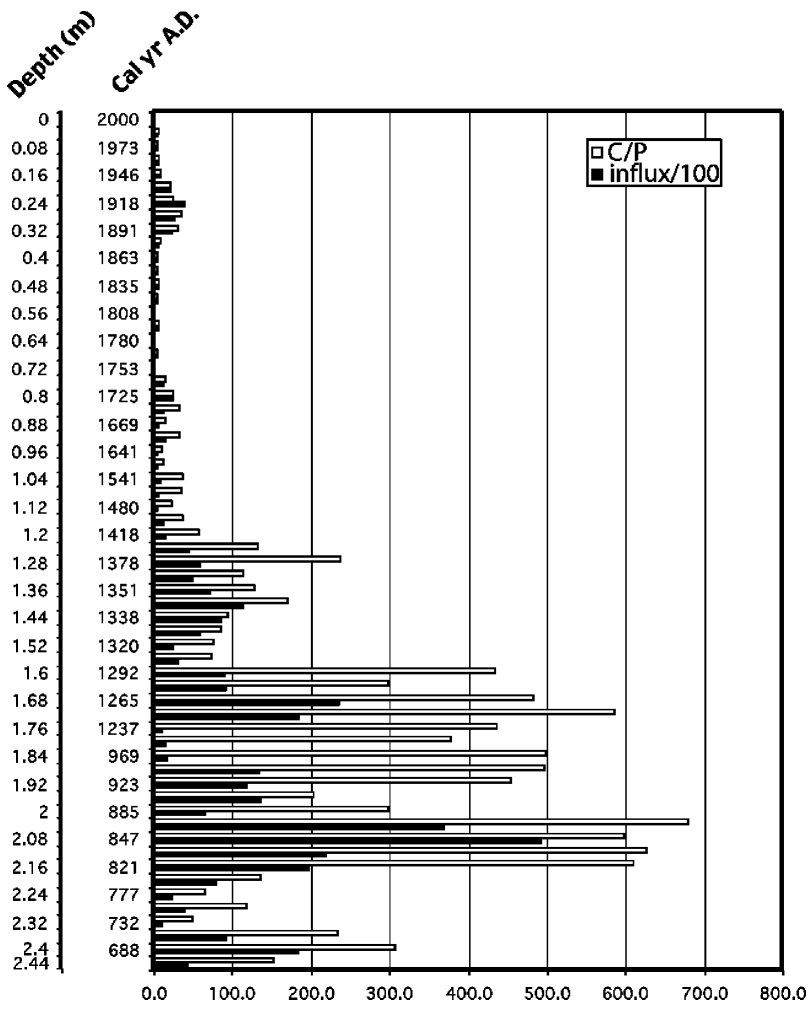

Figure 3. Comparison of charcoal influx data $\left(\mu \mathrm{m}^{2} \mathrm{~cm}^{-2} \mathrm{yr}^{-1}\right)$ with $\mathrm{C} / \mathrm{P}$ ratios (charcoal area / \# pollen grains). Linear regression of the two datasets yields $r^{2}=0.61$.

Charcoal influx and charcoal/pollen ratios $(\mathrm{C} / \mathrm{P})$ were calculated for the study interval. Linear regression of the two calculations yields $r^{2}=0.61$, but both are shown for ease of comparison with other studies (Fig. 3). Calculation

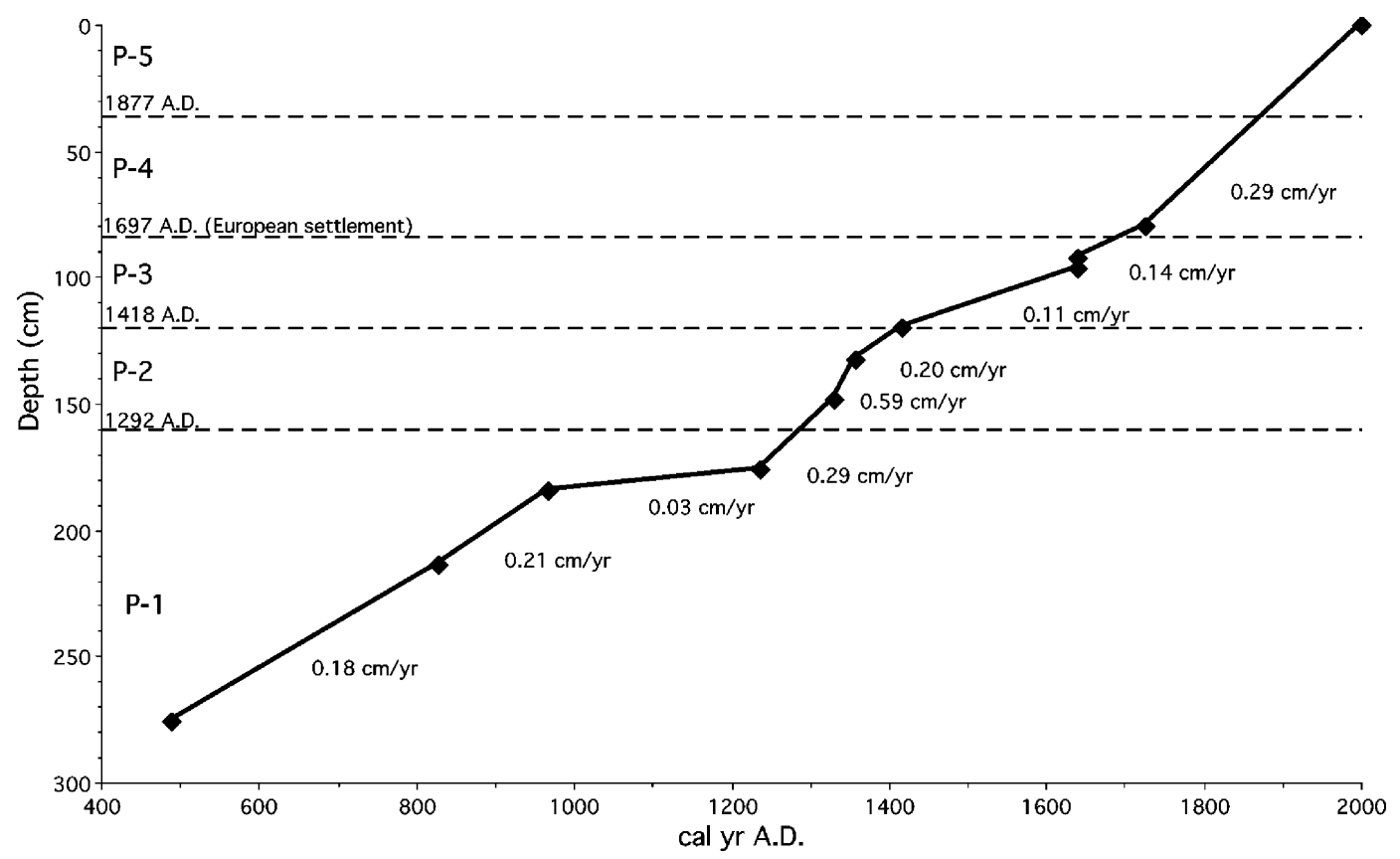

Figure 2. Linear interpolation of sedimentation rates for the Piermont Marsh core. Calculation of sedimentation rates assumes constant accumulation between dated layers. 
of $\mathrm{C} / \mathrm{P}$ ratios is conservative because the only criterion for counting was a minimum area of $500 \mu \mathrm{m}^{2}$. C/P ratios were calculated for each sample as follows:

$\mathrm{C} / \mathrm{P}=\frac{\text { charcoal area }\left(\mu \mathrm{m}_{2}\right)}{\text { \#pollen grains }}$

\section{Results}

Lithology, radiocarbon dating, age model, and sedimentation rates

The lithology for the study section is composed of peat, muck, and mucky peat (Fig. 4). Although the coring site is $100 \mathrm{~m}$ from the current course of Sparkill Creek, there are no channel deposits of coarser grained sediment in the core. The absence of any channel deposits supports continuous peat accumulation.

Radiocarbon dates from the core are mostly in stratigraphic order (Table 1). Two of seventeen dates were unusable due to contamination $(88-92 \mathrm{~cm}, 168-172 \mathrm{~cm})$. Ten of the remaining fifteen dates were used in the age model. We did not include dates from $108-112 \mathrm{~cm}, 132-$ 136 a cm, 140-144 cm, 188-192 cm, and 192-196 cm, which were omitted in favor of using marsh seed dates. Identified marsh seeds produced in situ have tough outer coats, impermeable to carbon contamination. Seeds take their carbon from the atmosphere and reflect the annual production rates of ${ }^{14} \mathrm{C}$ more accurately than bulk sediment dates, woody fragments, or charcoal stems. While macrofossils are subject to water transport to be incorporated in the peat profile, the non-seed material (i.e., wood and charcoal stems) may be contaminated by old carbon from the watershed itself, a correction that can be as great as $1000 \mathrm{yr}$ in the Hudson River (Olsen et al., 1978). Radiocarbon dates were converted to calibrated "calendar" dates using CALIB 4.4 (Stuiver and Reimer, 1993). Calendar age range is shown for 95.4\% enclosed area (2-sigma).

Because large changes in ${ }^{14} \mathrm{C}$ production for the time period spanned by this study can result in chronological uncertainties, several possible relative age ranges exist. Thus, dates selected for the age model were chosen on the basis of high relative area under the probability distribution within the $95.4 \%$ area enclosed. Cultural horizons, the most common being the increase in Ambrosia associated with permanent settlement, can be correlated to dates from historical records and have been used in studies focusing on more recent time scales (Brugam, 1978; Brush et al., 1982; Clark and Patterson, 1984; Davis, 1983; Davis et al., 1980; Fuller et al., 1998; Maenza-Gmelch, 1997; Russell et al., 1993; Willard and Korejwo, 1999). This adds to the chronologic control for this study.

\section{Pollen assemblages, organic content, and charcoal}

The core was divided into five pollen zones based on visual inspection. Objective zonation using CONISS confirms zone selection (Grimm, 1992). Specific zone age is based on the assumption of a constant accumulation rate between ${ }^{14} \mathrm{C}$-dated layers. Ages calculated by linear interpolation are marked with an asterisk (*).

\section{Zone P-1}

Pinus-Quercus zone (A.D. * 653-*1292; 246 to 160 $\mathrm{cm}$ ). Pinus and Quercus are the major pollen types (Fig. 4). Pinus is dominant and is composed of both haploxylon and diploxylon types, with broken grains preventing differ-

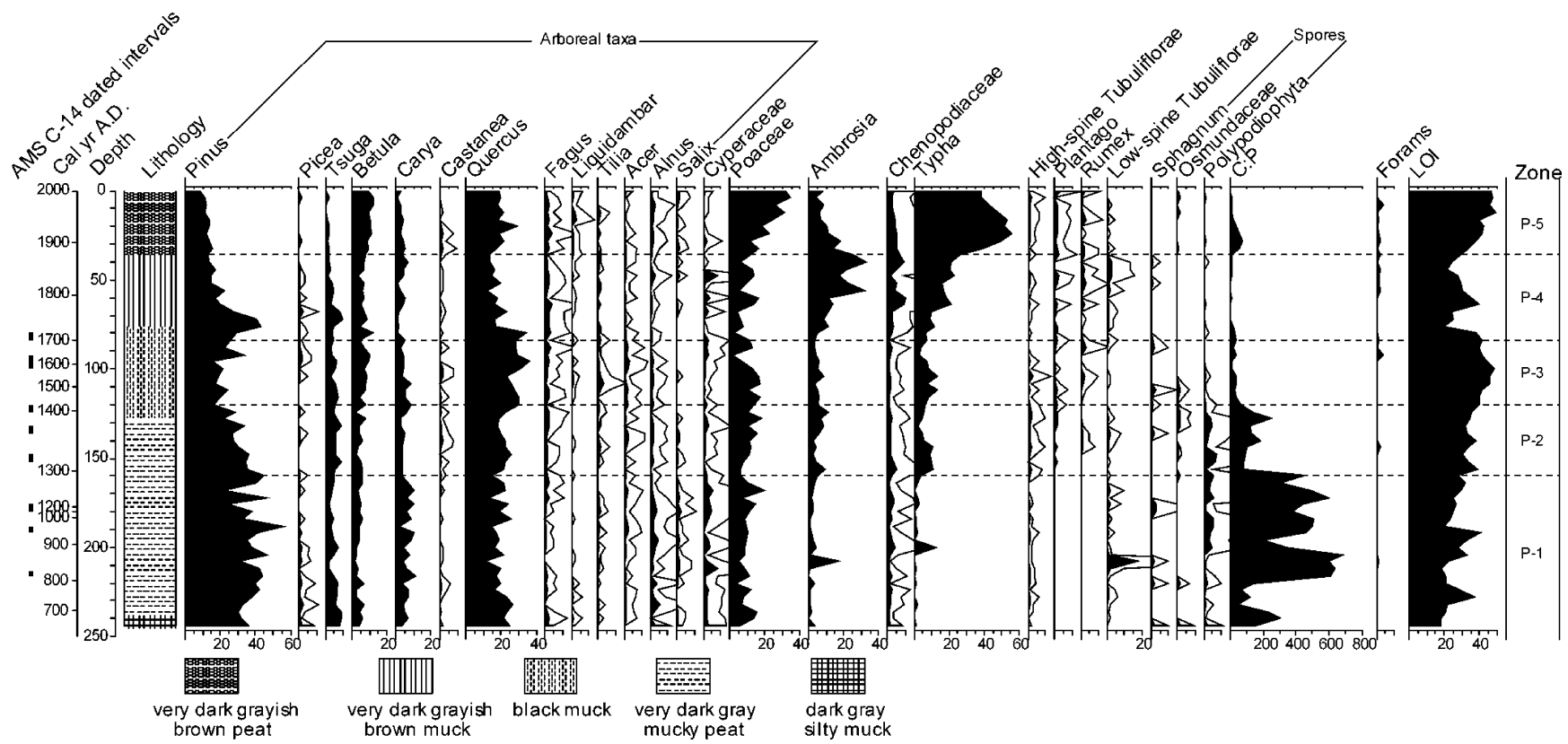

Figure 4. Percent data for Piermont Marsh pollen and spores. C/P ratios, forams, and LOI values are also shown. Exaggeration lines $(5 \times)$ are shown for minor taxa. 
entiation. Minor arboreal inputs from Tsuga, Betula, and Picea (spruce) are observed. Carya reaches its maximum percentage (11\%). Polypodiophyta percentages, although small, are consistently present in this zone.

Herbaceous pollen accounts for 10 to $14 \%$ of the pollen sum. Ambrosia and low-spine Tubuliflorae exhibit sharp peaks at $208 \mathrm{~cm}$. The total pollen accumulation rate (influx) reaches minimal values for the entire sequence (Fig. 5). LOI is variable, ranging between 20 and $40 \%$. Inorganic sediment mass contributions range from 0.16 to $0.72 \mathrm{~g}$, a maximum for the study interval (Fig. 6). Organic mass contributions are much more constant, ranging from 0.10 to $0.17 \mathrm{~g}$. C/P ratios are striking in magnitude when compared to the rest of the core; maximum values (135-679) are maintained throughout the zone (Figs. 4 and 6).

\section{Zone P-2}

Pinus-Quercus-Typha zone (A.D. *1292-1418; 160 $\mathrm{cm}$ to $120 \mathrm{~cm}$ ). Pinus (16 to 36\%) and Quercus (18 to 30\%) are the dominant arboreal species, with Pinus declining to the top of the zone. Rises in Poaceae (6-18\%), Ambrosia (3-11\%), and Typha (3-11\%) percentages are observed. Plantago and Rumex appear for the first time. Polypodiophyta are consistently present and reach a maximum of $7.8 \%$ during this interval.

LOI values for this zone increase and are less variable than in the previous zone, ranging from 28 to $39 \%$. The inorganic sediment fraction mass is also less variable than in the previous zones ( 0.18 to $0.29 \mathrm{~g}$ ), while the organic contribution remains similar to previous zones $(0.10$ to $0.14 \mathrm{~g})$. C/P

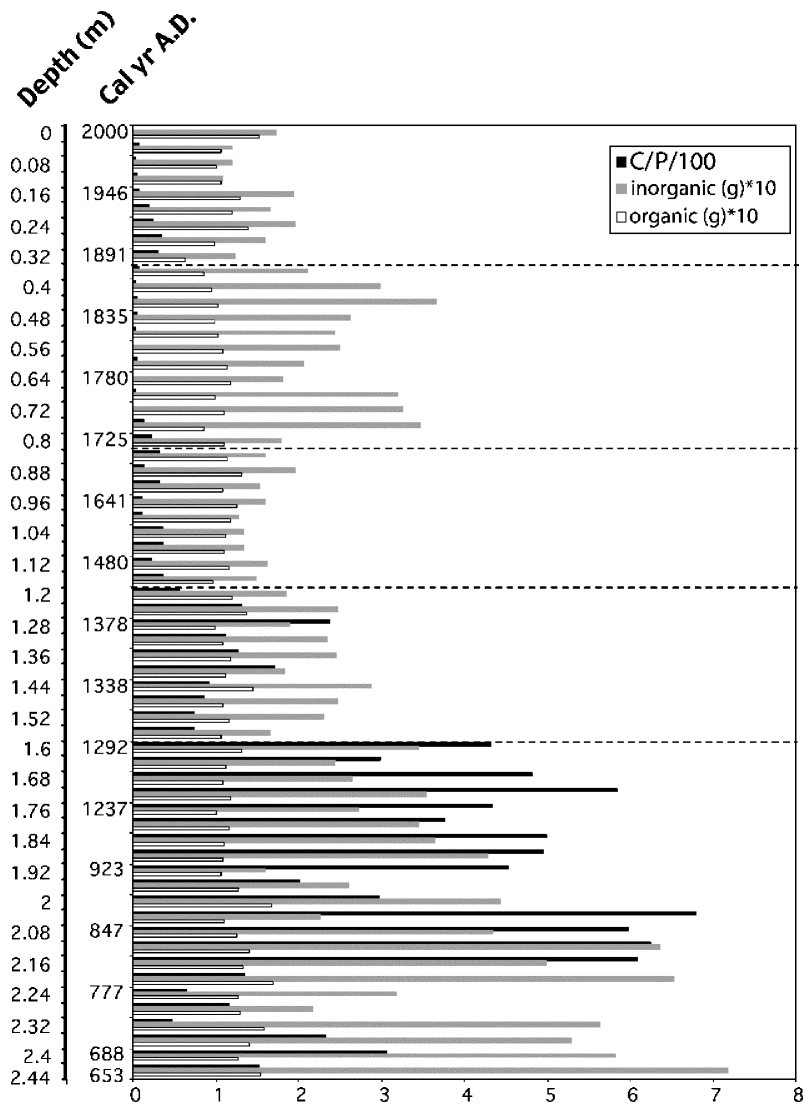

Figure 6. Sediment component masses and $\mathrm{C} / \mathrm{P}$ ratio data for the Piermont Marsh core. Inorganic and organic fractions are based on dry sample mass. Horizontal dashed lines mark pollen zones for comparison with pollen diagrams

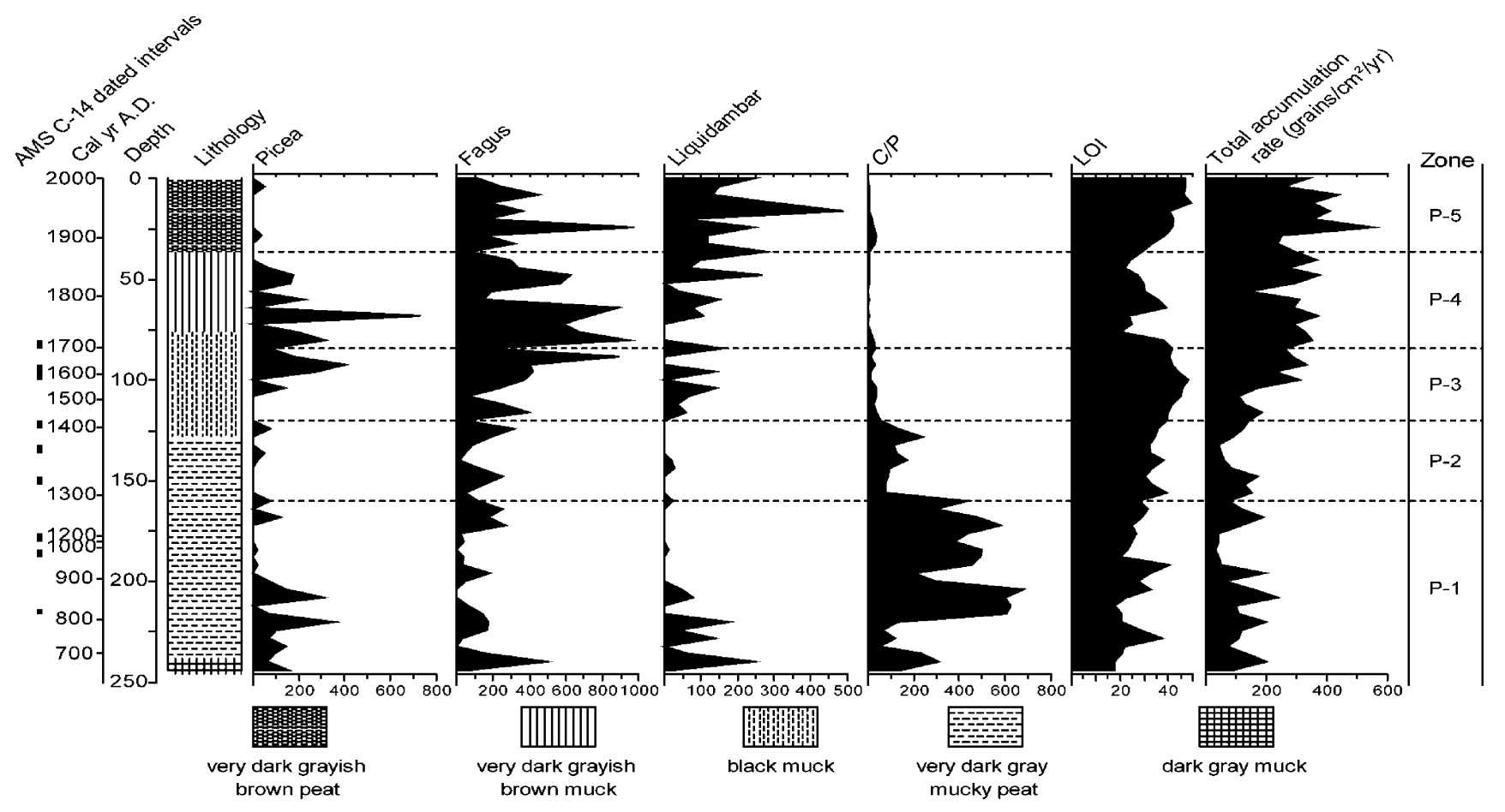

Figure 5. Selected pollen influx data mentioned in the text for Piermont Marsh with C/P ratios and LOI data. 
ratios are moderate and much lower than zone P-1 (57-237). Total pollen influx is variable and reaches values almost as low as those observed in the high charcoal zone, P-1.

\section{Zone P-3}

Quercus-Pinus-Betula zone (A.D. 1418-*1697; 120 $\mathrm{cm}$ to $84 \mathrm{~cm}$ ). For the first time in the record, Quercus (23 to $36 \%$ ) is present in equal and higher percentages than Pinus (16 to $33 \%$; Fig. 4). Pinus percentages increase slightly at the top of the zone, as does Picea. Betula also increases slightly (up to $12 \%$ ) from zone P-3. Polypodiophyta spores decline dramatically to zero.

$\mathrm{C} / \mathrm{P}$ ratios continue to decrease from P-3 (11-37). LOI increases to a zonal peak of $48 \%$ at $96 \mathrm{~cm}$. Both inorganic and organic fraction masses are relatively consistent for this zone. Inorganic mass ranges from 0.13 to $0.20 \mathrm{~g}$, and organic mass ranges from 0.10 to $0.13 \mathrm{~g}$. Decreasing C/P ratios complement the total pollen influx increase shown from the bottom to the top of the zone.

\section{Zone P-4}

Pinus-Quercus-Ambrosia-Typha zone (A.D. * *1697*1877; 84 to $36 \mathrm{~cm})$. Pinus and Quercus again are the dominant arboreal species, but both genera drop significantly as Ambrosia, Typha, and Poaceae increase (Fig. 4). The date of this zone is based on consistently high levels of Ambrosia (10\%) and corresponds to the timing of successful European settlement (A.D. 1681). Within the zone, there is a shift among major pollen types, as herbaceous taxa account for 10 to $51 \%$ of the pollen sum. Rumex and Plantago are more consistently present during this time, and species other than Ambrosia from the low spine Tubuliflorae family are consistently seen. A maximum is reached for Chenopodiaceae $(10 \%)$ mid-zone. Pinus decreases sharply from 43 to $13 \%$, Quercus drops to an average of $\sim 15 \%$, and Betula fluctuates between 4 and $12 \%$.

LOI values generally drop and are more variable (averaging $\sim 30 \%$ ) than in the previous zone and peak at $56-60 \mathrm{~cm}$. Inorganic sediment masses increase in this zone with peaks at 44 and $76 \mathrm{~cm}$, ranging from 0.18 to $0.36 \mathrm{~g}$ (Fig. 6). Organic masses decrease slightly from the previous zone and range from 0.06 to $0.12 \mathrm{~g}$. $\mathrm{C} / \mathrm{P}$ ratios reach minimum values for the record (0-31).

\section{Zone P-5}

Quercus-Typha-Poaceae zone (A.D. * 1877-2000); 36 to $0 \mathrm{~cm}$ ). Major pollen types are Typha (38 to $55 \%$ ), Quercus (17 to 29\%), and Poaceae (11 to 35\%). Ambrosia (4 to $18 \%$ ) drops off as the previously mentioned taxa increase. Typha percentages drastically increase. Pinus is still present in small amounts (9-16\%), and Betula reaches a plateau of $\sim 10 \%$ in the zone, which is a maximum for the entire study section. Plantago reaches a maximum value of $3 \%$ at the surface, and Rumex is still present.

LOI values increase to values similar to those in zone P-4. Inorganic masses drop abruptly from the previous zone with values from 0.20 to $0.11 \mathrm{~g}$. Organic masses increase slightly but remain similar to those in previous zones $(0.10$ to $0.15 \mathrm{~g}$ ). $\mathrm{C} / \mathrm{P}$ ratios are higher than zone $\mathrm{P}-4$ and are comparable to that seen in zone P-3 but decrease toward the surface.

\section{Discussion}

The Piermont Marsh changes in lithology and LOI, pollen and spores, charcoal, and macrofossils along with ${ }^{14} \mathrm{C}$ stratigraphy provide us with a high-resolution environmental history that is a primary record for this region. Additional cores from the marsh and nearby Hudson marshes (work in progress) will refine our understanding of the strengths and limitations of this unique site. Major changes in climate and human impact characterize the record.

\section{Pre-European Pinus-Quercus forest with droughts (A.D. $\sim^{* 653-* 1292)}$}

Dominant forest trees at $\sim$ A.D. 653 were Pinus and Quercus species. P. strobus was probably the dominant Pinus species as it is today, but $P$. rigida and $P$. resinosa were also likely present, as evidenced by both haploxylon and diploxylon pollen grains. While both $P$. rigida and $P$. resinosa are found in the modern regional landscape, $P$. rigida is more common. Other records from the lower Hudson Valley do not show the prevalence of Pinus (mean of 35\%) seen in the Piermont record (Fig. 4), but the record from a Staten Island marsh (D.S. Kleinstein, unpublished data, 2003) does show values as high as $25 \%$. In contrast, modern small lake records in the region (Loeb, 1989; Maenza-Gmelch, 1997) do not indicate Pinus percentages above $10 \%$. This suggests general site differences with more Pinus growing in the watershed than local lakes reveal, or an artifact of more fluvial and aerial transport of Pinus pollen to the marshes than to more protected small lakes. Future analysis of surface reference samples for modern pollen-vegetation relations will address this question. Quercus includes at least six species ( $Q$. alba, $Q$. rubra, $Q$. velutina, $Q$. bicolor, $Q$. prinus, and $Q$. coccinea), which are modern components of the Hudson River Valley (Little, 1971).

Loeb (1989) examined modern surface samples from several nearby lakes, and the most proximal to Piermont, Rockland Lake, shows a Quercus-dominated forest with values varying between 30 and $50 \%$ at the surface, contrasting with the Piermont record of $20 \%$ due to dilution by local marsh taxa such as Poaceae. While Quercus is typically one of the dominant arboreal taxa in most regional records (Buell et al., 1966; Carmichael, 1980; Clark and Patterson, 1985; D.S. Kleinstein, unpublished data, 2003; Maenza-Gmelch, 1997; Margraf, S.E., unpublished data, 2003; Russell, 1981), co-dominant species differ. To the north at Mohonk, NY (S.E. Margraf, unpublished data, 
2003) where mean July temperature is $2^{\circ} \mathrm{C}$ colder than the Piermont area, Betula is the dominant taxon as it is in some Massachusetts lakes to the northeast (Fuller et al., 1998). Betula, Fagus, Tsuga, and Acer were also present in small amounts at Piermont. The minor presence of Castanea at this time contrasts with other upland records from NY (Maenza-Gmelch, 1997; S.E. Margraf, unpublished data, 2003) and Connecticut (Brugam, 1978; Davis, 1969) where Castanea averages $10 \%$.

Noteworthy increases in Picea are seen here as conditions become dry and increased erosion from the north probably deposited more buoyant grains such as Picea (Fig. 4). Carya expands in the upper half of the zone, suggestive of warmer temperatures. Carya requires less moisture than other warm temperature indicator genera (i.e., Castanea) (Fowells, 1965). Shuman et al. (2004) demonstrate that midHolocene Carya expansion in New England occurred when temperatures were almost as warm as today based on hydrogen-isotope ratios. Forest and/or marsh fires were dominant in Piermont during this interval, as evidenced by high charcoal influx (Fig. 3). Pollen influx in the marsh is minimal, further suggesting loss of biomass and drier conditions leading to increased upland erosion which was then deposited in the marsh (Fig. 5). The increase in charcoal influx suggests several possible causes: (1) increased fire due to Native American activity, (2) increased river transport of buoyant material such as charcoal, or (3) a climate shift resulting in increased mortality due to drought that favored fire.

Native Americans often settled in river valleys, and those living in southern New England subsisted more on agricultural practices than from hunting alone (Cronon, 1983; Williams, 1989). Maintenance of fields and grasslands for berries and wild game prior to European settlement is a possible cause for increased burning (Williams, 1989), but large wildfires started by Native Americans are considered unlikely (Day, 1953; Russell, 1983). Natural disturbance or land clearance and maintenance by Native Americans in the large river valleys of northeastern North America (Day, 1953; Williams, 1989) would allow lightloving species such as Ambrosia to sporadically thrive prior to European settlement.

It is possible that changes in water transport played a role in the increase in charcoal and buoyant pine pollen during the time period coincident with the Medieval Warm Period (MWP). However, changes in the watershed source over the last millennium prior to European impact are unlikely, as geologic factors are insignificant on this time scale. We thus favor a climatic interpretation for the changes that take place in the Piermont record from $\sim$ A.D. 795-1290, corresponding to the timing of the Medieval Warm Period as defined by Lamb (1982) to be $\sim$ A.D. $800-1200$ in Europe and Greenland. Drier conditions at the landscape scale are supported by Pinus dominance, large increase in charcoal influx, and low pollen influx. Because the size criterion used for quantifying charcoal is based on sizes that yield more local information, the peaks in the record indicate local fires (within $20 \mathrm{~km}$ ). The expansion of more southern temperate taxa such as Carya and Liquidambar, along with the decline of Betula, Tsuga, and Alnus, suggests warmer and drier conditions. Isolated peaks in Poaceae and Ambrosia percentages also support the drought/increased fire hypothesis, as these taxa are more likely to colonize the landscape after a disturbance such as fire. The abundance of Ambrosia pollen $(17 \%)$ at $208 \mathrm{~cm}$ is noteworthy since percent values of $10 \%$ have been related to dates of European settlement; this sharp increase in Ambrosia is indicative of disturbance associated with increased charcoal (Clark, 1986; Clark and Patterson, 1985; Russell and Davis, 2001; Russell et al., 1993). Other nearby pollen studies show significant presence of Ambrosia (or Iva) much earlier than the first date of European settlement, further supporting the disturbance hypothesis for these early peaks (Carmichael, 1980; Clark, 1986). During this time, the only pollen types showing significant increases in both percent and influx data are Polypodiophyta and Salix. Increases in Salix and Polypodiophyta during this interval may reflect colonization of these species on expanding riverbanks as water level dropped.

Regional studies along the North Atlantic seaboard support our drought/fire hypothesis of the major shifts in Piermont Marsh. To the south along the Atlantic seaboard, Brush (1986) found warmer, drier conditions with increased charcoal from A.D. 1000-1200 in cores from Chesapeake Bay. Cronin et al. (2003) used $\mathrm{Mg} / \mathrm{Ca}$ based temperature reconstructions of ostracode shells to identify the first half of the MWP in their record. Sustained periods of drought from A.D. 1000 to 1300 are noted using tree-ring reconstructions from North Carolina (Stahle et al., 1988). While the periods of drought in each of these studies corresponds to times of high charcoal in Piermont, the record presented here reflects the full length of the classic MWP.

To the north, lake records from Black Rock Forest also demonstrate increased fire during this interval prior to European impact (Maenza-Gmelch, 1997). Several ponds in central Massachusetts show increased $\mathrm{C} / \mathrm{P}$ ratios during this interval; these locations are located in upland areas on poorer soils and are probably more sensitive to drought (Fuller et al., 1998). Other lake charcoal studies from the eastern US show that climate is an important influence on fire regimes (Clark and Royall, 1996; Parshall and Foster, 2002; Swain, 1973). However, many lower-resolution records from the NE US do not capture the importance of fire on the landscape during the MWP (Parshall et al., 2003; Russell et al., 1993).

Other North American records of the MWP have been demonstrated in the southwestern US (Cook et al., 2004, Stine, 1994). Midwestern US lake and dune records have also shown periods of drought during the MWP (Fritz et al., 2000; Mason et al., 2004). Recent speleothem studies record high ${ }^{18} \mathrm{O}$ values corresponding to the MWP in New Zealand 
(Williams et al., 2004). Documenting the global extent of this warm interval is important for understanding hemispheric linkages (Broecker, 2001).

\section{Forest Transition (A.D. * 1292-1418)}

During the next century, we see increases in more mesic species (Tsuga, Fagus) as Pinus and Chenopodiaceae decline. T. angustifolia is present consistently at the site, possibly indicating fresher conditions (Fig. 7). While this local marsh change may add more organic material to deposited sediment, a sharp decrease in inorganic input is evident from the raw data (Fig. 6). The plateau in organic mass and the corresponding decrease in inorganic mass leads us to conclude that the relative increase in LOI is due not to an increase in organic material but to a decrease in inorganic material. Charcoal influx decreases suggesting less fire, and the subsequent landscape stabilization encourages revegetation, reducing erosion, and the inorganic input to the marsh (Fig. 6). Relative organic content (LOI) rises as cool and moist conditions prevail with the onset of the Little Ice Age (LIA; A.D. 1400-1850; Lamb, 1982).

Little Ice Age and early European settlement (A.D. 1418*1697)

An expansion of Quercus and corresponding stabilization of Pinus characterizes this pre-European forest. Expansion of Tsuga forests indicates more available moisture, and the spread of northern genera such as Picea and Fagus suggests cooling, coinciding with the occurrence

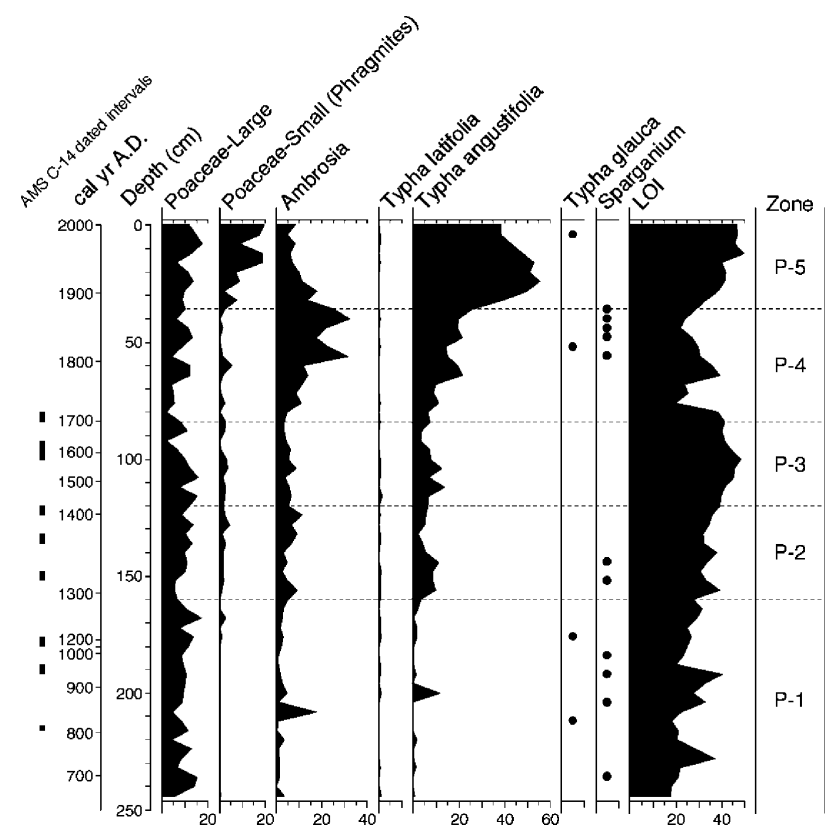

Figure 7. Pollen size separation data for Poaceae and Typha. Large Poaceae grains represent native marsh grasses, while small Poaceae grains correspond to Phragmites establishment. of the LIA. Lower charcoal influx (Fig. 3) and mineral content (Fig. 6) in the sediment indicate less drought stress and erosion of the landscape, further evidencing the presence of the LIA. Continued expansion of Poaceae and Ambrosia indicates disturbance by Native Americans and early Europeans. The Tappan tribe that occupied the surrounding area during this time period developed a strong agricultural and fishing society, complemented by winter hunting and trapping (Haagensen, 1986).

European settlement: Forest clearance, industry, and beginning of permanent agriculture (A.D. *1697_*1877)

The area was colonized by Europeans in A.D. 1681 (Haagensen, 1986). Thus, it is reasonable to attach a date of A.D. $* 1697$ to the marked, consistent Ambrosia rise. The Ambrosia rise is found in many pollen records from the northeast (Brugam, 1978; Carmichael, 1980; Clark, 1986; Clark and Patterson, 1985; Davis, 1969; Maenza-Gmelch, 1997; Russell and Davis, 2001; Russell et al., 1993). Other weedy species such as Chenopodiaceae, Plantago, and Rumex (Fernald, 1970) are also seen in greater abundance during this time. Decreases in the abundance of trees characterize the settlement period. Early settlers cleared the land for farms, homes, fuel, and ships. Dynamic changes in the local forest after settlement took place as Quercus and Pinus were felled for construction, fuel, and defense (masts, forts, etc.). Quercus, Carya, and Castanea were used for structures and fuel.

The Revolutionary War undoubtedly had a large impact on population and vegetation in this area. Vegetated shores along the river such as Stony Point and Fort Montgomery near the Bear Mountain Bridge were cleared for battles. Forests were burned to produce charcoal used in iron production (Cronon, 1983). The population of this area grew at times with increases in troop numbers (Haagensen, 1986). Rockland County, where Piermont Marsh is located, supported a population of 6000 in a 1790 census, an increase from the tally of 219 inhabitants in 1693 (Cole, 1884). This increase is probably a direct result of increased occupation during and after the war. Historic records of cold, snowy winters attest to the harsh conditions the people endured (Schechter, 2002).

The modern period of deforestation to reforestation: A.D. * 1877-2000

Deforestation on the landscape is dramatic with reduced presence of Pinus and Tsuga, as the Quercus forest recovers slightly in the 20th century. Much wood was needed in New York City to power steamboats and engines, and a convenient source would likely be this area because of proximity and easy river transport (Haagensen, 1986). A local brick factory in Haverstraw manufactured over 32 million bricks in 1883, which required enormous amounts of wood (Cole, 1884). The tanning industry used bark from 
Tsuga, accounting for its dramatic decrease (Russell et al., 1993). Betula, a disturbance species and less economically viable, becomes more abundant during this time, a trend observed in other NE US sites (Russell et al., 1993). These forest trends are observed in other areas of the northeast and likely indicate reforestation of cleared lands (Russell et al., 1993). In the last decade, the wooly adelgid has plagued Tsuga stand in the NE US, causing further decrease in this forest species (Orwig et al., 2002).

The anthropogenic influence emerges clearly in local marsh vegetation dominated primarily by Poaceae and Typha. A steady rise in Poaceae is visible as trees are felled but reaches greatest abundance during the last several decades, a pattern also visible in Jamaica Bay and Saw Mill Creek, which are NY marshes (Fig. 1a; D.S. Kleinstein, unpublished data, 2003; Peteet and Liberman, 2001) as well as in the Hackensack Meadowlands, New Jersey (Fig. 1; Carmichael, 1980). Recent Poaceae expansion is due to Phragmites invasion since the 1960s (Winogrond, 1997; Wong and Peteet, 1999). Clark and Patterson (1985) separated Poaceae based on size in a Long Island tidal marsh. Their size criteria were used in this study and support an increase in Phragmites in recent decades (Fig. 7). Size separation data also show the presence of Phragmites prior to European settlement, adding valuable information to the controversy of the native/introduced status of Phragmites. While native Phragmites has been present in the local marsh landscape over time, its recent dominance is attributed to introduced varieties that vary genotypically from the native types (Saltonstall, 2002).

Typha abundance in the marsh is maximal during the 20th century and is probably due to increases in eutrophication both from local and watershed-level nutrient inputs. Finkelstein (2003) separated Typha species based on morphology. T. latifolia has traditionally been thought of as a native species, while $T$. angustifolia is viewed as possibly an introduced species. The presence and dominance of $T$. angustifolia in the Piermont record indicate that T. angustifolia is not an introduced species. The presence of T. angustifolia/Sparganium is also documented from the Hackensack Meadowlands (Carmichael, 1980). Moreover, the presence of the hybrid T. glauca $\sim$ A.D. 800 indicates that $T$. angustifolia was present early enough for hybridization to occur.

\section{Marsh sediment composition and watershed implications}

Changes in organic and inorganic components in the Piermont Marsh sediments are intriguing. The input of organic material has been relatively constant throughout $(0.06$ to $0.15 \mathrm{~g})$, while the inorganic component has drastically decreased (from 0.72 to $0.11 \mathrm{~g}$ ) from A.D. 653 to the present (Fig. 6). This inorganic decline is complemented by a relatively consistent proportion of water (62 to $88 \%$ ) in the samples, suggesting that de-watering of clays is not a factor for these changes. If core compaction played a role in sediment characteristics, higher pollen influx would be evident in the deeper sections of the record (Brugam, 1978). Pollen influx is actually much lower at the base of the record than at the surface, indicating that compaction is minimal.

The gradual decrease in inorganic material upcore suggests several possible mechanisms. Climate change probably accounts for the signature of watershed erosion to the marsh because the MWP with drought and high fire records large inorganic inputs while the cooler, wetter LIA inputs to the marsh are minimal. A dry, burned landscape is more susceptible to removal of inorganics than one that is heavily vegetated, further supporting the drought hypothesis. Another possibility is relative sea level fluctuation, as Piermont creek banks receive more inorganic matter than the internal high marsh. Tectonism could also have affected relative sea level, as the area is faulted (Newman et al., 1987).

Humans have also affected erosion. European impact is clearly marked as an abrupt increase in inorganic content from about A.D. 1700 to 1875 , but the magnitude of the rise is not equivalent to MWP inputs. This landscape clearance that resulted in higher inorganic supply parallels the increases in weedy species. Previous estuarine work has shown drastic increases in sedimentation rates after land clearance, due to increased runoff and erosion (Brush, 1984, 1989; Brush et al., 1982; Neubauer et al., 2002; Pasternack et al., 2001).

Subsequent declines in Piermont Marsh inorganic content in the twentieth century support revegetation of the watershed. Eutrophication has especially influenced the expansion of Typha and Phragmites on the marsh itself.

\section{Conclusions}

(1) Pollen stratigraphy from Piermont Marsh reveals the pre-European forest composition (A.D. 653-1697) as Pinus-Quercus forest with minor inputs from Tsuga, Betula, and Carya.

(2) The MWP is present from A.D. 800 to 1300 as indicated by increases in Pinus and Carya, declines in Quercus, the inconsistent presence of Picea, decreases in drought-sensitive species (Tsuga, Betula, Alnus), and large increase in fire. Higher inorganic content (erosion) and low pollen influx during this interval further support the drought hypothesis.

(3) The subsequent LIA (A.D. 1400-1850) is evident from Picea peaks, increases in Tsuga and Cyperaceae, and minimal erosion (low inorganic component) of the watershed.

(4) European impact in the 18th century is striking with increases in local marsh species such as Typha. The spread of weedy genera such as Ambrosia, Plantago, and Rumex indicates upland disturbance until the 20th century, when they decline with reforestation. 
(5) Charcoal abundance is greatest coincident with the MWP and suggests that fire frequency is mediated primarily by climate (drought) in the Hudson watershed.

(6) Inorganic inputs to the marsh are highest at the initiation of this record, decreasing toward the present. European impact shows resurgence in the inorganic fraction, resulting from changes in land use. Continued research on a suite of Hudson River marshes will further elucidate the influences of drought and fire in the Hudson Valley.

\section{Acknowledgments}

This research was funded by the Hudson River Foundation, the LDEO Investment Fund, and a Director's Discretionary Fund grant from NASA. Discussions with Wally Broecker, Erica Hendy, Neil Pederson, Kirsten Sauer, and two anonymous reviewers improved the manuscript. Sample material used in this project was stored in the LDEO Sample Repository. The National Science Foundation (Grant OCE00-02380) and the office of Naval Research (Grant N00014-02-1-0073) provide support for the collection and curating facilities of the repository. Thanks to Cara Peters and Lauren Hamill for initial pollen processing. This is Lamont contribution number 6714.

\section{References}

Blair, E.A., Nieder, W.C., 1993. Mapping of the Hudson River NERR: Creating Tools for Tidal Wetland Research, Management, and Education. Final report to the Hudson River Foundation. New York, NY.

Bond, G.C., Kromer, B., Beer, J., Muscheler, R., Evans, M.N., Showers, W., Hoffman, S., Lotti-Bond, R., Hajdas, I., Bonani, G., 2001. Persistent solar influence on North Atlantic climate during the Holocene. Science 294, 2130-2136.

Broecker, W.S., 2001. Was the medieval warm period global? Science 291, 1497-1499.

Brugam, R.B., 1978. Pollen indicators of land-use change in southern Connecticut. Quaternary Research 9, 349-362.

Brush, G.S., 1984. Patterns of recent sediment accumulation in Chesapeake Bay (Virginia-Maryland U.S.A.) Tributaries. Chemical Geology 44, 227-242.

Brush, G.S., 1986. Geology and paleoecology of Chesapeake Bay: a longterm monitoring tool for management. Journal of the Washington Academy of Sciences 76, 146-160.

Brush, G.S., 1989. Rates and patterns of estuarine sediment accumulation. Limnology and Oceanography 34, 1235-1246.

Brush, G.S., Martin, E.A., DeFries, R.S., Rice, C.A., 1982. Comparisons of $210 \mathrm{~Pb}$ and pollen methods for determining rates of estuarine sediment accumulation. Quaternary Research 18, 196-217.

Buell, M.F., Langford, A.N., Davidson, D.W., Ohmann, L.F., 1966. The upland forest continuum in northern New Jersey. Ecology 47, $416-432$.

Carmichael, D., 1980. A record of environmental change during recent millenia in the Hackensack tidal marsh, New Jersey. Bulletin of the Torrey Botanical Club 107, 514-524.

Clark, J.S., 1986. Late-Holocene vegetation and coastal processes at a Long Island tidal marsh. Journal of Ecology 74, 561-578.
Clark, J.S., 1988. Particle motion and the theory of charcoal analysis: source area, transport, deposition, and sampling. Quaternary Research $30,67-80$

Clark, J.S., Patterson III, W.A., 1984. Pollen, Pb-210, and opaque spherules: an integrated approach to dating and sedimentation in the intertidal environment. Journal of Sedimentary Petrology 54, 1251-1265.

Clark, J.S., Patterson III, W.A., 1985. The development of a tidal marsh: upland and oceanic influences. Ecological Monographs 55, 189-217.

Clark, J.S., Robinson, J., 1993. Paleoecology of fire. In: Crutzen, P.J, Goldhammer, J.G. (Eds.), Fire in the Environment: The Ecological, Atmospheric and Climatic Importance of Vegetation Fires. John Wiley and Sons Ltd., New York, pp. 193-214.

Clark, J.S., Royall, P.D., 1996. Local and regional sediment charcoal evidence for fire regimes in pre-settlement north-eastern North America. Journal of Ecology 84, 365-382.

Cole, D., 1884. History of Rockland County New York. J.B. Beers and Co., New York.

Cook, E.R., Jacoby Jr., G.C., 1977. Tree-ring drought relationships in the Hudson Valley, New York. Science 198, 399-401.

Cook, E.R., Woodhouse, C., Eakin, C.M., Meko, D.M., Stahle, D.W., 2004. Long-Term Aridity Changes in the Western United States. Science 306, $1015-1018$.

Cronin, T.M., Dwyer, G.S., Kamiya, T., Schwede, S., Willard, D.A., 2003. Medieval Warm Period, Little Ice Age and 20th century temperature variability from Chesapeake Bay. Global and Planetary Change 36, 17-29.

Cronon, W., 1983. Changes in the land: Indians, Colonists, and the Ecology of New England. Hill and Wang.

Davis, M.B., 1969. Climatic change in southern Connecticut recorded by pollen deposition at Rogers Lake. Ecology 50, 409-422.

Davis, M.B., 1983. Holocene vegetational history of the eastern United States. In: Wright, H.E. (Ed.), Late-Quaternary Environments of the United States, vol. 2. University of Minnesota Press, Minneapolis, pp. $166-181$.

Davis, M.B., Spear, R.W., Shane, L.C.K., 1980. Holocene climate of New England. Quaternary Research 14, 240-250.

Day, G.M., 1953. The Indian as an ecological factor in the Northeastern forest. Ecology 34, 329-346.

Dean, W.E., 1974. Determination of carbonate and organic matter in calcareous sediments and sedimentary rocks by loss on ignition: comparison with other methods. Journal of Sedimentary Petrology 44, $242-248$.

Faegri, K., Iversen, J., 1975. Textbook of Pollen Analysis. Hafner Publishing Company, New York.

Fernald, M.L., 1970. Gray's Manual of Botany. Van Nostrand Company, New York.

Finkelstein, S.A., 2003. Identifying pollen grains of Typha latifolia, Typha angustifolia, and Typha x glauca. Canadian Journal of Botany 81, 985-990.

(FNAEC) Flora of North America Editorial Committee (Eds.), (1993). Flora of North America North of Mexico, vols. 7+. Oxford University Press, New York.

Fowells, H.A. (Ed.), 1965. Silvics of Forest Trees of the Untied States. U.S. Department of Agriculture Forest Service, Washington, DC.

Fritz, S.C., Ito, E., Yu, A., Laird, K., Engstrom, D.R., 2000. Hydrologic variation in the Northern Great Plains during the last two millennia. Quaternary Research 53, 175-184.

Fuller, J.L., Foster, D.R., McLachlan, J.S., Drake, N., 1998. Impact of human activity on regional forest composition in central New England. Ecosystems 1, 76-95.

Grimm, E.C., 1992. TILIA and Tilia-Graph Software, Version 2.0. Illinois State University.

Haagensen, A.M., 1986. Palisades and Snedens Landing. Pilgrimage Publishing, Tarrytown, NY.

Heusser, L.E., Stock, C.E., 1984. Preparation techniques for concentrating pollen from marine sediments and other sediments with low pollen density. Palynology 8, 225-227. 
Kapp, R.O., Davis, O.K., King, J.E., 2000. Pollen and Spores. American Association of Stratigraphic Palynologists Foundation Publication.

Keigwin, L., 1996. The Little Ice Age and Medieval Warm Period in the Sargasso Sea. Science 274, 1504-1508.

Lamb, H.H., 1982. Climate, History and the Modern World. Methuen, London.

Lehr, J.H., 1967. The marshes at Piermont, New York: a field report. Sarracenia $11,31-34$

Lewis, W.H., Vinay, P., Zenger, V.E., 1983. Airborne and Allergenic Pollen of North America. The Johns Hopkins University Press, Baltimore, MD

Little Jr., E.L., 1971. Atlas of United States trees: Volume 1 Conifers and Important Hardwoods. USDA Forest Service Miscellaneous Publication 1146.

Loeb, R.E., 1989. Lake pollen records of the past century in northern New Jersey and southeastern New York, U.S.A. Palynology 13, 3-19.

Maenza-Gmelch, T.E., 1997. Holocene vegetation, climate, and fire history of the Hudson Highlands, southeastern New York, USA. The Holocene $7,25-37$

Mason, J.A., Swinehart, J.B., Goble, R.J., Loope, D.B., 2004. LateHolocene dune activity linked to hydrological drought, Nebraska Sand Hills, USA. The Holocene 14, 209-217.

Merley, M., Peteet, D., 2001. Salt marsh formation in the lower Hudson River estuary. EOS Transactions AGU 82 (20), S87 (Spring Mtg Suppl, Abstract B41B-12).

Moore, P.D., Webb, J.A., 1978. An Illustrated Guide to Pollen Analysis. John Wiley and Sons, New York.

Neubauer, S.C., Anderson, I.C., Constantine, J.A., Kuehl, S.A., 2002. Sediment deposition and accretion in a mid-Atlantic (U.S.A.) tidal freshwater marsh. Estuarine, Coastal and Shelf Science 54, 713-727.

Newman, W.S., Cinquemani, L.J., Sperlin, J.A., Marcus, L.F., Pardi, R., 1987. Holocene neotectonics and the Ramapo Fault sea-level anomaly: a study of varying marine transgression rates in the Lower Hudson Estuary, New York and New Jersey. In: Nummendal, D., Pilkey, O.H., Howard, J.D. (Eds.), Sea Level Fluctuation and Coastal Evolution. Society of Economic Paleontologists and Mineralogists, Tulsa, pp. 97-111.

Olsen, C.R., Simpson, H.J., Bopp, R.F., Williams, S.C., Peng, T.-H., Deck, B.L., 1978. A geochemical analysis of the sediments and sedimentation in the Hudson estuary. Journal of Sedimentary Petrology 48, 401-418.

Orwig, D.A., Foster, D.R., Mausel, D.L., 2002. Landscape patterns of hemlock decline in New England due to the introduced hemlock woolly adelgid. Journal of Biogeography 29, 1475-1487.

Parshall, T., Foster, D.R., 2002. Fire on the New England landscape: regional and temporal variation, cultural and environmental controls. Journal of Biogeography 29, 1305-1317.

Parshall, T., Foster, D.R., Faison, E., MacDonald, D., Hansen, B.C.S., 2003. Long-term history of vegetation and fire in pitch pine-oak forests on Cape Cod, Massachusetts. Ecology 84, 736-748.

Pasternack, G.B., Brush, G.S., Hilgartner, W.B., 2001. Impact of historic land-use change on sediment delivery to a Chesapeake Bay subestuarine delta. Earth Surface Processes and Landforms 26, 1-19.

Peteet, D.M., Liberman, L., 2001. Millennial Climate and Land use History from Jamaica Bay Marshes. New York Geologic Society of America Annual Meeting, Boston, MA., pp. A-453

Peteet, D.M., Wong, J.K., 1999. Late Holocene environmental change from NY-NJ estuaries. Abstracts-Northeastern Geological Society of America, p. 65 .
Russell, E.W.B., 1981. Vegetation of northern New Jersey before European settlement. The American Midland Naturalist 105, 1-12.

Russell, E.W.B., 1983. Indian-set fires in the forests of the Northeastern United States. Ecology 64, 78-88.

Russell, E.W.B., Davis, R.B., 2001. Five centuries of changing forest vegetation in the Northeastern United States. Plant Ecology 155, $1-13$.

Russell, E.W.B., Davis, R.B., Anderson, R.S., Rhodes, T.E., Anderson, D.S., 1993. Recent centuries of vegetational change in the glaciated north-eastern United States. Journal of Ecology 81, 647-664.

Saltonstall, K., 2002. Cryptic invasion by a non-native genotype of the common reed, Phragmites australis, into North America. Proceedings of the National Academy of Sciences 99, 2445-2449.

Schechter, B., 2002. The Battle for New York. Walker and Company, New York.

Shuman, B., Newby, P., Huang, Y., Webb III, T., 2004. Evidence for the close climatic control of New England vegetation history. Ecology 85 (5), $1297-1310$

Stahle, D.W., Cleveland, M.K., Hehr, J.G., 1988. North Carolina climate change reconstructed from tree rings: A.D. 372 to 1985 . Science 240, $1517-1519$.

Stine, S., 1994. Extreme and persistent drought in California and Patagonia during mediaeval time. Nature 369, 546-549.

Stuiver, M., Reimer, P.J., 1993. Extended ${ }^{14} \mathrm{C}$ database and revised CALIB radiocarbon calibration program. Radiocarbon 35, 215-230.

Swain, A.M., 1973. A history of fire and vegetation in northeastern Minnesota as recorded in lake sediments. Quaternary Research 3, $383-396$

Tinner, W., Hu, F.S., 2003. Size parameters, size-class distribution and area-number relationship of microscopic charcoal: relevance for fire reconstruction. The Holocene 13, 499-505.

Trenberth, K., Overpeck, J., Solomon, S., 2004. Exploring drought and its implications for the future. EOS 87 (3), 27.

Willard, D.A., Korejwo, D.A., 1999. Holocene Palynology from MarionDufresne cores MD99-2209 and 2207 from Chesapeake Bay: impacts of climate and historic land-use change. In: Cronin, T.M. (Ed.), Initial Report on IMAGES V Cruise of the Marion-Dufresne to the Chesapeake Bay June 20-22, 1999. United States Geological Survey, Reston, VA, pp. 78-86. Open file report 00-306.

Willard, D.A., Cronin, T.M., Verardo, S., 2003. Late-Holocene climate and ecosystem history from Chesapeake Bay sediment cores, USA. The Holocene 13 (2), 201-214.

Williams, M., 1989. Americans and Their Forests. Cambridge Univ. Press.

Williams, P.W., King, D.N.T., Zhao, J.-X., Collerson, K.D., 2004. Speleothem master chronologies: combined Holocene $18 \mathrm{O}$ and $13 \mathrm{C}$ records from the North Island of New Zealand and their palaeoenvironmental interpretation. The Holocene 14, 194-208.

Winogrond, H.G., 1997. Invasion of Phragmites australis in the Tidal Marshes of the Hudson River, M.S. thesis. Bard College, Annandale-on-Hudson, New York.

Wong, J.K., Peteet, D., 1999. Environmental history of Piermont Marsh, Hudson, River, NY. In: Nieder, W.C., Waldman, J.R. (Eds.), Final Reports of the Tibor T. Polgar Fellowship Program, 1998. Hudson River Foundation. Section III. p. 30.

Wright Jr., H.E., Mann, D.H., Glaser, P.H., 1984. Piston corers for peat and lake sediments. Ecology 65, 657-659. 